Afier middie age tioere is a steady increase in the amoun: of davcume sleep and $a$ decrease in night sieep, despite an increased time in bed at night. This is due to increasing disturbance to sleep with age-increased delay in getting off to sleep, more frequent and longer awakenings during the night, and earlier morning awakening. The change is very prominent in patients with chronic brain syndrome (Feinberg. 1967). In some respect this represents a gradual return to the polyphasic pattern of sleep seen in children, presumably as a result of degenerative changes in the central nervous system.

The present analysis of symptoms and sleep disturbances showed that men with chronic symptoms of cardiovascular disease (particularly ischaemic heart disease), as well as those complaining of multiple physical symptoms as a result of neurotic illness, have significantly increased degrees of sleep disturbance at all ages. This is manifested in the reduced duration of sleep and increased time spent awake in bed at night. As a diagnostic group the patients with ischaemic heart disease reported the most sleep disturbance. Some of these patients had evidence of significant neurotic illness, presenting as anviety, depression, or multiple minor complaints which often follow acute episodes of heart disease. They may also have had a disorder of their sleep mechanisms as part of a more widespread disorder of their diurnal rhythms which is manifested, for example, in decreased or absent diurnal variation in plasma corticosteroid concentrations (Knapp, 1969).

As was suggested by Weiss et al. (1962), gastrointestinal, genitourinary, musculoskeletal, and respiratory symptoms alone dic not usualiy cause significant long-term sleep disturbance, though there may be exceptions to this. When sucsymptoms were also associated with neurotic illness, however. they tended to be associated with sleep disturbance. It is no: possible to say whether any of the symptoms arose as a resu: of long-term sleep deprivation

We thank Professor H. A. F. Dudiey for help in the preparation of this paper.

Requests for reprints should be addressed to Dr. M. W. Johns, Department of Surgery, Monash University Medical School, Commercial Road, Prahran, Victoria 3181, Australia.

\section{REFERENCES}

Brodman, K., Erdmann, A. J., Lorge, I., and Wolff, H. G. (1949 fournal of the American Medical Association, 140, 530 .

Culpan, R. H., Davies. B. M., and Oppenheim, A. N. (1960). British Medical fournal, 1, 855.

Feinberg, I. (1967). Research Publications, Association for Research in Nervous and Mental Disease, 45, 211.

Hawkins, D. R., and Mendels, J. (1968). American Fournal of Psychiatry, 123, 682 .

Knapp, M. S. (1969). Fournal of the Royal College of Physicians of London, 3, 398.

Lewis, S. A. (1969). British fournal of Psychology, 60, 203.

McGhie, A. (1966). British fournal of Medical Psychology, 39, 221

McGhie. A., and Russell, S. M. (1962). fournal of Mental Science, 108. 642 .

Monroe, L. J. (1967). Fournal of Abnormal Psychology, 72, 255

Rudolf, G. de M. (1955). Medical Press, 233, 324.

Tune, G. S. (1968). British Medical fournal, 2. 269.

Tune, G. S. (1968). British Medical fournal, 2. 269.

Tune, G. S. (1969). British fournal of Medical Psychology, 42, 75. Psychology, 8, 2.

Weiss, H. R., Kasinoff, B. H., and Bailey, M. A. (1962). fournal of Nervous and Mental Disease, 134, 528.

\title{
Use of Vaccinia Virus in the Treatment of Metastatic Malignant Melanoma
}

\author{
I. HUNTER-CRAIG, ${ }^{*}$ M.A., M.CHIR., F.R.C.S. ; K. A. NEWTON, † F.R.C.P., F.F.R.
}

G. WESTBURY, $\ddagger$ M.B., F.R.C.S., M.R.C.P. ; B. W. LACEY, $\$ M.D., F.R.C.PATH., F.I.BIOL.

British Medical fournal, 1970, 2, 512-515

\begin{abstract}
ummary: Of 19 patients with proved metastases from malignant melanoma treated by inoculations of smallpox vaccine, intradermal deposits disappeared completely in six out of ten cases. Five of these remained well 2 to 22 months after initial treatment. The response was limited strictly to the site of inoculation. The mechanism of action of vaccinia virus in malignant melanoma is not clear.
\end{abstract}

\section{Introduction}

It has been known for many years that viruses might inhibit the growth of malignant tumours. DePace (1912) aroused interest in the clinical use of viruses with his description of a woman who gained remission of her cervical carcinoma following rabies vaccination for a dog-bite. Since then various workers using live virus have attempted to reproduce this effect, though mostly with negative results, and Southam and Moore (1952) have stressed the great obstacles to any practical use of viruses.

Pack (1950) suggested that rabies vaccine might inhibit the course of malignant melanoma. Other workers have used

\footnotetext{
* Consultant Surgeon, Redhill Group of Hospitals, Redhill, Surrey. † Consultant Radiotherapist, Westminster Hospital, London S.W.1. ¥ Consultant Surgeon, Westminster Hospital, London S.W.1.

$\checkmark$ Professor of Bacteriology, Westminster Hospital, London S.W.1.
}

standard smallpox vaccine (vaccinia virus) in malignant melanoma, and have reported regressions of both cutaneous and visceral lesions (Burdick, 1960; Belisario and Milton, 1961; Burdick and Hawk, 1964; Milton and Lane Brown, 1966). We report our experience with vaccinia virus in the treatment of selected cases of malignant melanoma.

\section{Methoả}

As a rule small cutaneous lesions were cleaned with spirit, allowed to dry completely, smeared with smallpox vaccine (Lister Institute sheep lymph containing about $2 \times 10^{8}$ pockforming units per ml.), and either scarified or pricked repeatedly with a needle. Sometimes the vaccine was injected into the lesion with a Pan Jet $\|$ adjusted to deliver $0.1 \mathrm{ml}$. per shot intradermally. Bulky cutaneous lesions, subcutaneous deposits, and on one occasion a lymph node metastasis were infiltrated with up to $3 \mathrm{ml}$. of a one in three dilution of vaccine from a tuberculin syringe. Iniormed consent was obtained from the patients undergoing this procedure.

One patient was inoculated intravenously with about $2 \times$ $10^{8}$ pock-forming units of sheep-derived vaccinia virus kindly supplied by Dr. H. G. S. Murray (Lister Institute). This preparation had been freeze-dried with sorbitol and Place, Woodhouse Road, London N.12. 
sodium glutamate and was reconstituted immediately before injection. Only one patient had not been previously vaccinated against smallpox, and this single exception was vaccinated in the normal way with a successful primary take one month before tumour inoculation. Nevertheless, with a view to minimizing the risk of dangerous reactions to the relatively large doses used, the first six previously vaccinated patients were revaccinated before tumour inoculation.

\section{Results}

From January 1968 to September 196919 patients with histologically proved deposits were treated, six on more than one occasion. Intradermal deposits disappeared completely in 6 out of 10 cases. No subcutaneous or lymph-node deposits disappeared in response to treatment (Table I)..Response was limited strictly to the site of vaccination; lesions remote from or even. adjacent to the site of inoculation were unaffected. shown histiocytes laden with pigment, but no tumour. In two patients tumours recurring at or near sites previously treated were inoculated with further vaccine. The first (Case 1) responded well to further tumour inoculation five and nine

TABLE II.-Details of Patients with Intradermal Deposits

\begin{tabular}{|c|c|c|c|c|c|c|}
\hline $\begin{array}{l}\text { Case } \\
\text { No. }\end{array}$ & Age & Sex & Primary & Metastases & $\begin{array}{l}\text { Response to } \\
\text { Vaccination }\end{array}$ & Follow-up \\
\hline $\begin{array}{l}1 \\
2 \\
3 \\
4 \\
5\end{array}$ & $\begin{array}{l}37 \\
52 \\
52 \\
48 \\
59\end{array}$ & $\begin{array}{l}\mathbf{F} . \\
\mathbf{F} . \\
\mathbf{F} . \\
\mathbf{F} .\end{array}$ & $\begin{array}{l}\text { Knee } \\
\text { Leg } \\
\text { Antle } \\
\text { Back } \\
\text { Calf }\end{array}$ & $\begin{array}{l}\text { Graft } \\
\text { Thigh } \\
\text { Scar } \\
\text { Graft } \\
\text { Foot and leg }\end{array}$ & $\begin{array}{l}\text { Complete } \\
\text { Complete } \\
\text { Complete } \\
\text { Complete } \\
\text { Complete }\end{array}$ & $\begin{array}{l}\text { Well at } 22 \text { months } \\
\text { Well at } 11 \text { months } \\
\text { Well at } 7 \text { months } \\
\text { Well at } 7 \text { months } \\
\text { Alive with recur- }\end{array}$ \\
\hline $\begin{array}{l}6 \\
7\end{array}$ & $\begin{array}{l}74 \\
60\end{array}$ & F. & Calf & $\begin{array}{l}\text { Scar } \\
\text { Leg }\end{array}$ & $\begin{array}{l}\text { Complete } \\
\text { Partial }\end{array}$ & $\begin{array}{l}\text { Well at } 2 \text { months } \\
\text { Alive with discase }\end{array}$ \\
\hline $\begin{array}{l}8 \\
9\end{array}$ & $\begin{array}{l}38 \\
66\end{array}$ & $\begin{array}{l}\mathbf{M} . \\
\mathbf{F}\end{array}$ & $\begin{array}{l}\text { Leg } \\
\text { Foot }\end{array}$ & $\begin{array}{l}\text { Leg } \\
\text { Foot and leg }\end{array}$ & $\begin{array}{l}\text { Nil } \\
\text { Partial }\end{array}$ & $\begin{array}{l}\text { Lost to follow-up } \\
\text { Alive with recur- } \\
\text { rence at } 5\end{array}$ \\
\hline 10 & 49 & F. & Leg & Graft & . Partial & $\begin{array}{c}\text { months } \\
\text { morminglly }\end{array}$ ill at 3 \\
\hline
\end{tabular}

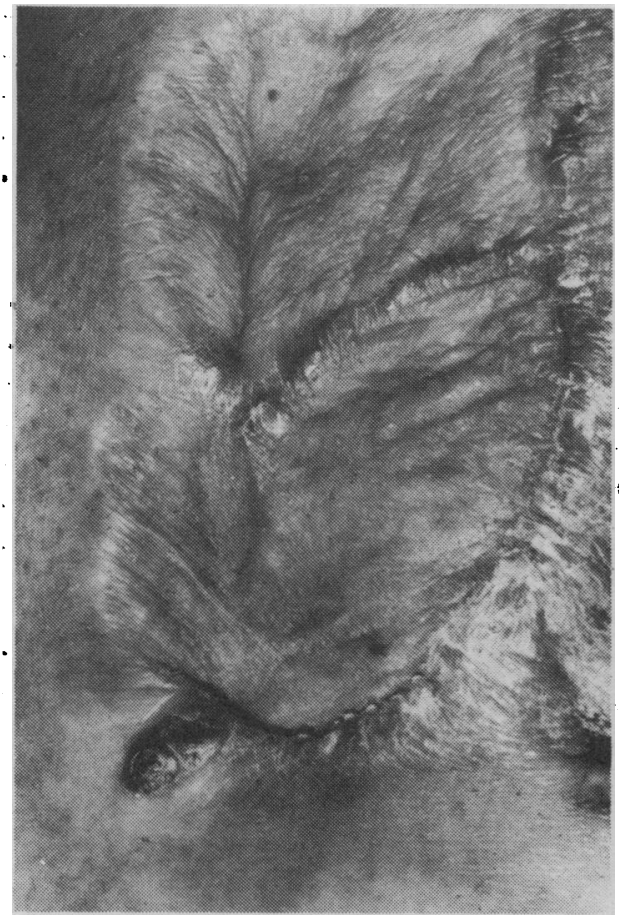

Fig. 1.-Case 1. Recurrent nodule of malignant melanoma in the graft area.
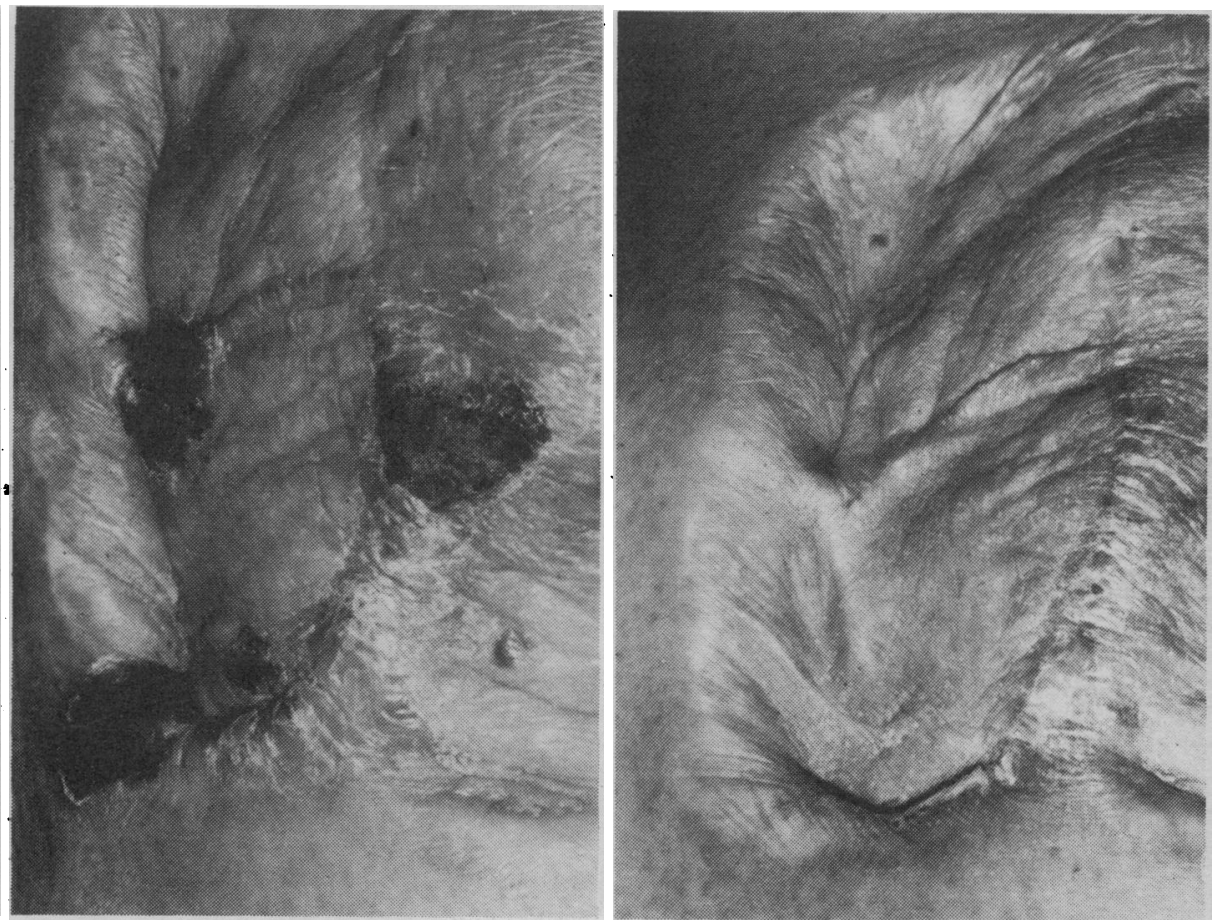

FIG. 2.-Case 1. Scabbing following vaccination of the nodules after six weeks.
TABLE I.-Response of Malignant Melanoma Deposits to Vaccinia Virus

\begin{tabular}{c|c|c|c|c|c}
\hline \multirow{2}{*}{ Location of Deposits } & & $\begin{array}{c}\text { No. of } \\
\text { Patients }\end{array}$ & \multicolumn{2}{c}{ Response } \\
\cline { 4 - 6 } & & & Complete & Partial & Nil \\
\hline $\begin{array}{l}\text { Intradermal } \\
\text { Subcutaneous and lymph node }\end{array}$ & $\ldots$ & 9 & 6 & 3 & 1 \\
\hline
\end{tabular}

Among patients with intradermal deposits there was no obvious clinical difference between those whose lesions disappeared and those whose lesions were unaffected by vaccination (Table II).

Successful inoculation of an intradermal lesion was shown by vesicle formation, proceeding to scabbing. After separation of the scab a healed and often depigmented patch of skin remained. On other occasions residual, impalpable, densely pigmented spots have been seen. Biopsy of such areas has months following initial treatment, and remained clinically disease-free two years from her first attendance. The second (Case 9) developed new intradermal deposits five months after the initial treatment. Repeated vaccination produced little local reaction and her tumours proved completely refractory to a third series of inoculations.

One patient with disseminated disease involving skin and viscera, who showed a partial response to a test inoculation to a single subcutaneous deposit, was given a large dose of virus intravenously $\left(2 \times 10^{8}\right.$ pock-forming units) without benefit or harm. Successful tumour vaccination was sometimes accompanied by general malaise and low-grade pyrexia for 24 to 72 hours. No severe systemic reaction was seen.

Of six patients showing complete response to tumour inoculation five remained well without clinical evidence of disease 2 to 22 months after initial treatment; one has fresh active deposits. 


\section{Case 1}

A married woman aged 37 underwent wide excision and splitskin grafting for a malignant melanoma of the right prepatellar region in February 1967, followed one week later by prophylactic ilioinguinal node dissection. She was referred to Westminster Hospital in December 1967 with histologically proved local recurrences in the graft. As she had not previously been vaccinated against smallpox she was vaccinated in the normal way and developed a normal major reaction. One month later, in January 1968, the nodules were inoculated. There was pronounced local reaction with vesiculation and scabbing, but no systemic upset. After separation of the scabs the nodules were still present though greatly reduced in size (Fig. 1). They were reinoculated in March with further brisk local reaction (Fig. 2) followed by complete disappearance. In June and again in October several new nodules appeared in the grafted area and one nodule on the medial aspect of the thigh midway between the primary area and the groin. These were successfully reinoculated on each occasion and she has since remained free from clinical evidence of disease (Fig. 3). pigmented spots (Fig. 6). Histological examination of one such spot showed histiocytes laden with pigment but no melanoma cells. The patient has remained well.

\section{Discussion}

The results obtained in this series resemble in general those already reported. The best responses have been in patients with intradermal deposits, whereas subcutaneous and lymph node metastases respond poorly or not at all. Belisario and Milton (1961) and Burdick and Hawk (1964) described cases in which local tumour vaccination led to both local and widespread tumour regression, but, as we have shown, in the present series response has been limited strictly to the site of vaccination. Milton and Lane Brown (1966) reported that a good response was always accompanied by considerable systemic reaction. We have sometimes noted excellent local responses without systemic side-effects. The same authors
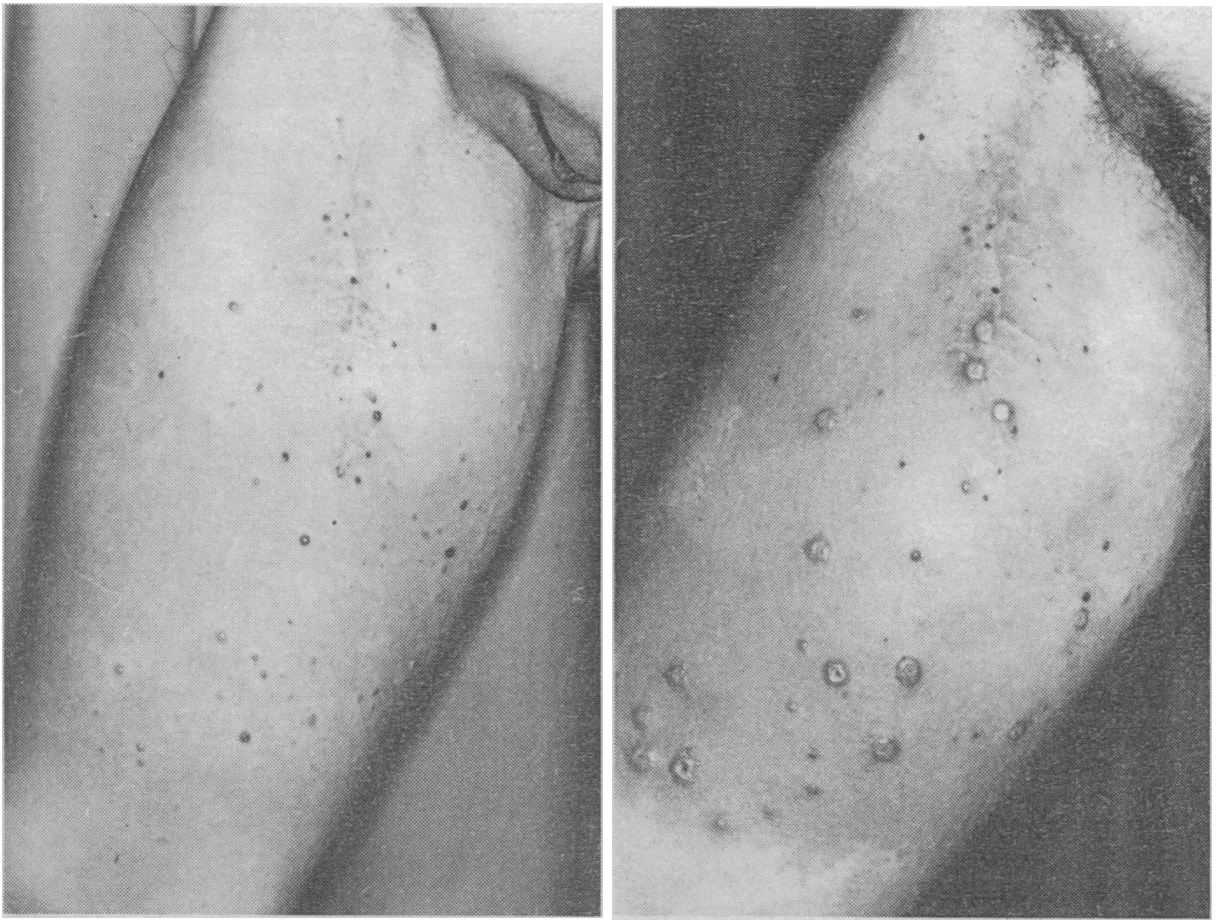

FIG. 4.-Case 2. Recurrent intradermal deposits of malignant melanoma.
FIG. 5.-Case 2. Reaction at the site of vaccination with surrounding erythema after 21 days.

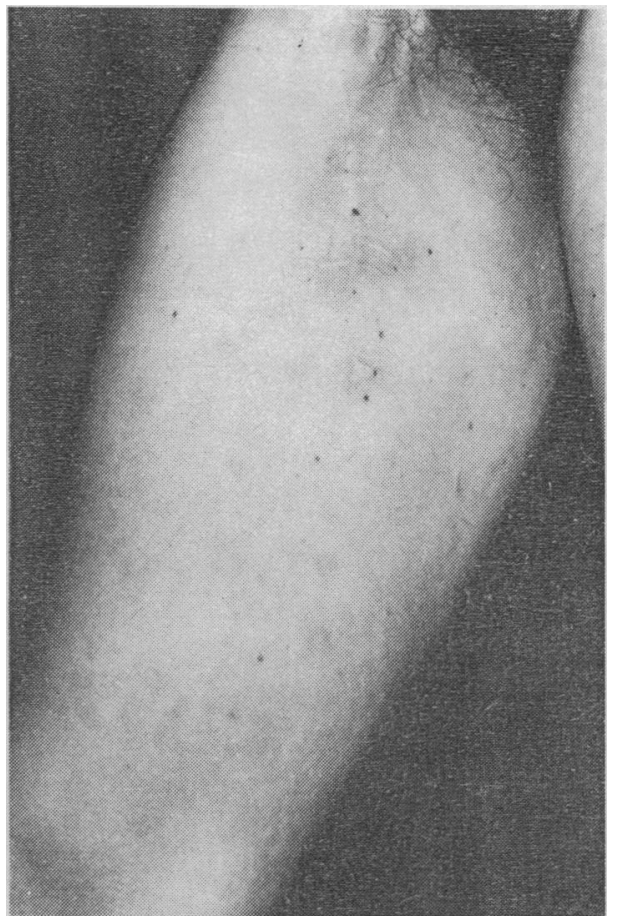

FIG. 6.-Case 2. Resolution of lesion. A few impalpable pigmented spots remain eight months after vaccination.

\section{Case 2}

A married woman aged 52 underwent excision and split-skin grafting for malignant melanoma of the right leg in January 1968. This was followed by dissection of the inguinal nodes, which contained metastases. She was referred to Westminster Hospital in November 1968 with multiple pigmented and non-pigmented intradermal deposits, scattered over the medial aspect of the right thigh (Fig. 4). An intra-arterial infusion of the cytotoxic agent mitopodozide was set up, but was discontinued after a total of only $9 \mathrm{~g}$. because the catheter blocked. This relatively small dose, as expected, produced no clinical effect. Five days later 50 lesions were inoculated with vaccine by the Pan Jet and all reacted characteristically with vesiculation proceeding to scabbing (Fig. 5) There was an accompanying systemic reaction, with fever, rigors, and malaise. An area of skin bearing 32 deposits was deliberately left untreated, showing no change six weeks later; these remaining lesions were inoculated, and over the next three weeks the freshly treated deposits scabbed over, unaccompanied by systemic reaction. All lesions continued to regress, leaving only a few impalpable also claimed that smallpox vaccination within the previous five years precluded a satisfactory tumour response. As already noted, we deliberately vaccinated or revaccinated patients in the early part of the series shortly before tumour inoculation without apparent reduction in tumour response. This observation is of some interest since it suggests that virus growing in or near the tumour may be relatively inaccessible to antibody or other immune factors.

The mode of action of vaccinia virus in malignant melanoma is not clear. An obvious possible mechanism is a direct cytopathic effect by the virus on the melanoma cells, and there is evidence that viruses may enjoy better intracellular propagation in neoplastic cells than in the normal (Southam and Moore, 1952). Burdick and Hawk suggested that the action of the virus might be the result of non-specific stimulation of the patient's immune response. Old et al. (1961), Weiss et al. (1961), and Halpern et al. (1964) quoted evidence in support of such a mechanism. On the same basis 
Mathé et al. (1968) prolonged the periods of remission in patients with acute leukaemia, using B.C.G. Burdick and Hawk looked for autoantibodies in the serum of their patient after successful treatment, but failed to show any cytotoxic activity of the serum in vitro. This is not surprising, since they used isologous (not autologous) melanoma cells, and, as Lewis et al. (1969) showed, cytotoxic antibodies directed against the surface antigens of malignant melanoma cells are specific for each individual tumour; cross-reactions do not occur with cells from other patients.

Another possibility is that the inflammation caused by the virus might allow cytotoxic autoantibodies or cytotoxic lymphocytes to come into better contact with tumour cells. Lewis et al. (1969) showed that most patients with localized melanoma possess cytotoxic autoantibodies. It would thus be of interest to know the immunological status of patients treated with vaccinia, and further work to test these hypotheses is being carried out by one of us (I. H.-C.) in a collaborative effort with the Chester Beatty Research Institute. It is hoped that this will be the subject of a subsequent report.

At present direct inoculation of tumour deposits offers a safe and simple method of control of locally advanced malignant melanoma, particularly when the disease is intradermally situated. The remissions so far achieved compare favourably with those seen following regional cytotoxic therapy or irradiation. With regard to the possibility of vaccination for early potentially curable disease, we consider it unwise to depart from the orthodox surgical approach on present evidence, for the following reason: local recurrence after excision is in some instances due to failure to remove adjacent invisible satellite foci. The response to vaccination, in our experience and in most recorded instances, is strictly localized to the site of inoculation, and such satellite foci might well escape treatment, with adverse effect on the course of the disease.

Our thanks are due to the surgeons and physicians who kindly referred cases under their care. We are also grateful to Professor Peter Alexander, of the Chester Beatty Research Institute, for his helpful advice, and to Dr. Peter Hansell and the department of medical photography at Westminster Hospital, who kindly provided the illustrations.

\section{REFERENCES}

Belisario, J. C., and Milton, G. W. (1961). Australian fournal of Dermatology, 6, 113.

Burdick, K H (1960). Archives of Dermatology, 82, 438.

Burdick, K. H., and Hawk, W. A. (1964). Cancer (Philadelphia), 17, 708 .

DePace, N. (1912). Ginecologia (Firenze), 9, 82

Halpern, B. N., et al. (1964). Fournal of the Reticuloendothelial Society, 1,77 .

Lewis, M. G., et al. (1969). British Medical fournal, 3, 547.

Mathé, G., et al. (1968). Revue Française d'Etudes Cliniques et Biologiques, 13, 454.

Milton, G. W., and Brown, M. M. L. (1966). Australian and New Zealand fournal of Surgery, 35, 286.

Old, L. J., Benacerraf, B., Clarke, D. A., Cartwell, E. A., and Stockert, E. (1961). Cancer Research, 21, 1281.

Pack, G. T. (1950). Archives of Dermatology and Syphilology, 62, 694.

Southam, C. M., and Moore, A. E. (1952) Cancer (Philadelphia), 5, 1025.

Weiss, D. W., Bonhag, R. S., and DeOme, K. B. (1961). Nature, 190, 889.

\title{
Comparison of the Effect of Alprenolol and Propranolol on Specific Airway Conductance in Asthmatic Subjects
}

\author{
C. K. CONNOLLY, ${ }^{*}$ M.A., M.B., M.R.C.P. ; J. C. BATTEN, $†$ M.D., F.R.C.P.
}

\begin{abstract}
Cummary : Alprenolol did not cause a significant fall in the mean of the specific airway conductance in nine asthmatic subjects who did show a significant fall with propranolol. Thus alprenolol is not contraindicated in asthmatic subjects, though it should be used with caution intravenously, as one subject showed a substantial fall in airway conductance at three minutes which recovered within 30 minutes. Until further studies are completed these results should not be applied to bronchitics with increased airway resistance.
\end{abstract}

\section{Introduction}

Drugs which block beta-adrenergic receptors are contraindicated in asthma. The resting endogenous beta-adrenergic activity, which may be considerable even in remission, is counteracted. This produces a rise in airway resistance (Richardson and Sterling (1969). Alprenolol (1-(2-allylphenoxy)-3-isopropylamino-2-propanol) blocks beta-adrenergic receptors but also stimulates them ( $\AA$ blad, 1967; Åblad, Brogård, and Ek, 1967). This modifies its haemodynamic effects and the resting cardiac output remains unaltered after intravenous injection (Forsberg and Johnsson,

*First Assistant to the Department of Medicine, St. George's Hospital, London S.W.1.

tConsultant Physician, St. George's Hospital, London S.W.1.
1967). The net effect of the dual action of alprenolol on bronchial calibre in asthma is probably small (Beumer, 1968). We have compared alprenolol and propranolol in a doubleblind study.

\section{Subjects and Methods}

Nine subjects with mild to moderate asthma, unchanged for three months, were studied. No aerosols (including cigarette smoke) were allowed on the day of the test. Therapy was otherwise unchanged. Informed consent for these studies was obtained in every case.

A solution of $10 \mathrm{mg}$. of alprenolol in $10 \mathrm{ml}$. of water and a similar preparation of propranolol were provided in identical numbered phials. The solution was administered intravenously. Each drug was given to the subjects in a random order, unknown to the patient and the observer. The interval between experiments was from 6 to 15 days. Airway resistance (Raw) and thoracic volumes (Vtg) were measured in the body plethysmograph. Readings were made direct from the oscillograph. They were checked in most cases with a photographic record, which gave similar results. Three separate estimations were made at each time. Readings were made at 15-minute intervals for half an hour before and one hour after injection. Additional readings were taken at three minutes (the 